\title{
Bromelain Activity of Waste Parts of Two Pineapple Varieties
}

\section{Edmund Ofosu Benefo ${ }^{*}$ and Isaac Williams Ofosu}

\author{
Department of Food Science and Technology, Kwame Nkrumah University of Science and \\ Technology, Kumasi, Ghana \\ aebenefo@gmail.com
}

Keywords: pineapple waste, bromelain, enzyme activity

\begin{abstract}
Bromelain, a protease found in pineapples, is of high demand in the pharmaceutical, cosmetic and food industries. Along the pineapple processing chain, waste products such as peels, crowns, stems and cores result. These parts are usually discarded, though they contain significant amounts of the enzyme bromelain. This study sought to determine the bromelain activity of the crowns and peels of two pineapple varieties grown in Ghana; MD2 and Sugarloaf. The crude extract was obtained by homogenising the peels and crowns in a cold phosphate buffer and centrifuging at $3000 \mathrm{rpm}$ for $15 \mathrm{~min}$. Ethanol and ammonium sulphate precipitation were carried out on the extract between $30 \%-80 \%$ precipitation levels. The enzyme activity was determined using the casein digestion method. Results showed that bromelain was precipitated mainly in the $30 \%-60 \%$ precipitation range. Sugarloaf crowns yielded the highest enzyme activity of $20.82 \mathrm{U} / \mathrm{ml}$ and a specific activity of $194.58 \mathrm{U} / \mathrm{mg}$ at the $40 \%$ ammonium sulphate precipitation level. This was followed by the Sugarloaf peels with an enzyme activity of $19.98 \mathrm{U} / \mathrm{ml}$ at $50 \%$ ethanol precipitation level. Ethanol precipitation resulted in fractions with lower bromelain activity. Enzyme activity was higher in the Sugarloaf variety and also in the crowns of both varieties. The two pineapple varieties have significant levels of bromelain activity and could be exploited for commercialisation.
\end{abstract}

\section{Introduction}

Bromelain is distributed in different parts of the pineapple. The specific part of from which it is extracted lends its name to the enzyme, thus we have fruit bromelain and stem bromelain [1]. Bromelain activity has been reported to be within a $\mathrm{pH}$ range of 3 to 8 and a temperature range of $30-70{ }^{\circ} \mathrm{C}[2-4]$.

In the food industry, bromelain has found widespread use as a meat tenderiser, anti-browning agent and in the production of infant formulas [5]. As a protease, it hydrolyses proteins in these formulas, thus making amino acids more readily available to infants. Cosmetic and pharmaceutical usage of bromelain, as well as usage in the textile industry, have also been reported [6-9].

Several methods have been employed in the extraction and purification of bromelain with varying success. However, the initial sample homogenisation step remains essentially the same. The sample is homogenised in phosphate buffer $(0.1 \mathrm{M}, \mathrm{pH} 7.0)$ with a blender and then centrifuged to remove plant fibres and other impurities [10-13]. Purification of enzymes is important in order to determine the three dimensional structure of an enzyme and its impact on the functionality of the enzyme [14]. Researchers have succeeded in purifying bromelain using techniques such as aqueous two phase systems [15-16], ammonium sulphate precipitation [10-11], ethanol precipitation [12], ion exchange chromatography [10, 11, 13], membrane separation [17] and adsorption using functionalized Santa Barbara Acid-15 [18].

Enzymatic activity is defined as the amount of enzyme that catalyses the reaction of $1 \mu \mathrm{mol}$ of a substrate under specified conditions [19]. This definition gives room for a researcher to calculate enzymatic activity based on the conditions under which the work was done. Yet, it presents a difficulty when comparing the enzymatic activity of samples experimented on under different conditions. Whereas some researchers opt for the casein digesting unit method, others opt for the gelatin digesting unit method.

Ghana produces about 661,500 tonnes of pineapple annually [20]. Waste, accounting for $35-$ $40 \%$ of the pineapple mass, is produced during pineapple processing [21]. These waste parts (peels, 
crowns, stems and core) have a low commercial value and are discarded or in a few cases composted to be used in fertilising soils. The activity of bromelain in pineapples highly varies within different varieties, geographical and climatic conditions [5]. The objective of this study was to determine the activity of bromelain extracted from the peels and crowns of the MD2 and Sugarloaf pineapple varieties cultivated in Ghana.

\section{Materials and Methods}

Source of Materials: The pineapples (Sugarloaf and MD2 varieties) were sourced from a pineapple farm at Adipa near Nsawam in the Eastern region of Ghana.

Crude Bromelain Extraction: The crude extract was obtained by homogenising the peels and crowns in cold phosphate buffer $(0.1 \mathrm{M}, \mathrm{pH}$ 7.0) using a Waring blender (Model 8010ES, Waring Commercial, Connecticut, USA). The extract was filtered with a cheesecloth and centrifuged at $3000 \mathrm{rpm}$ for $15 \mathrm{~min}$ to remove all insoluble material using a MSE Beun De Ronde Centrifuge. The supernatant was retained for further analysis and the sediment discarded.

Ethanol and Ammonium Sulphate Precipitation: This was done following the method of [22]. The crude extract was kept on ice and cooled ethanol added to it to achieve concentrations of $30-80 \%(\mathrm{v} / \mathrm{v})$. Solid ammonium sulphate was added in bits to other fractions of the crude extract to achieve saturations of $30-80 \%$. The mixtures were stirred to ensure dissolution of ammonium sulphate and left to stand for $30 \mathrm{~min}$ for precipitation to continue. All mixtures were then centrifuged at $3000 \mathrm{rpm}$ for $15 \mathrm{~min}$. The respective sediments were recovered and solubilised in $20 \mathrm{ml}$ of phosphate buffer ( $20 \mathrm{mM}, \mathrm{pH} 7.0)$.

Enzyme Activity Assay: The enzyme activity was determined according to the casein digestion method as described by [23]. The assay mixture contained $5 \mathrm{ml}$ of freshly prepared $1 \%$ casein which was prewarmed at $37^{\circ} \mathrm{C}$ to be used as substrate and $1 \mathrm{ml}$ of the solubilised bromelain added. The mixture was vortexed immediately (Vortex Genie, Wilton and Co. B.V.) and incubated at $37{ }^{\circ} \mathrm{C}$ for $10 \mathrm{~min}$. The reaction was stopped by the addition of $5 \mathrm{ml}$ of $1 \%$ Trichloroacetic acid. The reaction mixture was filtered and the absorbance of the filtrate was measured at $280 \mathrm{~nm}$ using a Nanodrop ND 1000 Spectrophotometer (Thermo Fisher Scientific, US). Using tyrosine as a standard, concentrations of $50 \mu \mathrm{g} / \mathrm{ml}, 100 \mu \mathrm{g} / \mathrm{ml}, 150 \mu \mathrm{g} / \mathrm{ml}, 200 \mu \mathrm{g} / \mathrm{ml}$, and $250 \mu \mathrm{g} / \mathrm{ml}$ were prepared and their absorbance read at $280 \mathrm{~nm}$. A standard curve of tyrosine absorbance against tyrosine concentration was plotted. One unit of bromelain activity was defined as the amount of bromelain required to produce $1 \mu \mathrm{mol}$ of tyrosine after 1 minute of digestion of a standard casein substrate at $37^{\circ} \mathrm{C}$.

Statistical Analysis: Data was analysed using Statistical Package for Social Scientists (SPSS) version 22. Analysis of Variance (ANOVA) was performed to determine differences between means and Tukey test to determine significant differences at the $95 \%$ confidence interval level.

\section{Results and Discussion}

The bromelain activity, specific activity, purification factor and yield of the various fractions of the precipitated bromelain are presented in the Tables 1-8. In this study, 1 unit of bromelain activity has been defined as the amount of bromelain required to produce $1 \mu$ mol of tyrosine after 1 minute of digestion of a standard casein substrate at $37^{\circ} \mathrm{C}$. The specific activity is ratio of the amount of units of enzyme activity of a particular fraction to its protein concentration. The specific activity is used as an index of the purity of the enzyme fraction; the higher the specific activity, the purer the enzyme. The purification factor is the ratio of the specific activity of an enzyme fraction to the specific activity of the starting fraction (crude extract). It measures how effective each purification step is. The yield of a purification step is the ratio of the enzyme units retained after that step to the enzyme units that were present in the starting fraction (crude extract) expressed as a percentage. The yield measures how well the enzyme activity has been preserved or retained. 
Table 1. Ethanol precipitation of bromelain extract from $M D 2$ crowns $^{1}$

\begin{tabular}{|l|c|c|c|c|}
\hline \multicolumn{1}{|c|}{ Fraction } & $\begin{array}{c}\text { Bromelain } \\
\text { activity, } \\
{[\mathbf{U} / \mathbf{m l}]}\end{array}$ & $\begin{array}{c}\text { Specific } \\
\text { activity, } \\
{[\mathbf{U} / \mathbf{m g}]}\end{array}$ & $\begin{array}{c}\text { Purification } \\
\text { factor }\end{array}$ & Yield, [\%] \\
\hline Crude extract & $20.71^{\mathrm{a}}$ & $64.72^{\mathrm{a}}$ & & \\
\hline $30 \%$ & $11.36^{\mathrm{b}}$ & $183.23^{\mathrm{b}}$ & $2.83^{\mathrm{a}}$ & $54.85^{\mathrm{a}}$ \\
\hline $40 \%$ & $14.28^{\mathrm{c}}$ & $185.45^{\mathrm{c}}$ & $2.87^{\mathrm{b}}$ & $68.95^{\mathrm{b}}$ \\
\hline $50 \%$ & $18.01^{\mathrm{d}}$ & $159.38^{\mathrm{d}}$ & $2.46^{\mathrm{c}}$ & $86.96^{\mathrm{c}}$ \\
\hline $60 \%$ & $12.27^{\mathrm{e}}$ & $219.11^{\mathrm{e}}$ & $3.39^{\mathrm{d}}$ & $59.25^{\mathrm{d}}$ \\
\hline $70 \%$ & $8.92^{\mathrm{f}}$ & $202.73^{\mathrm{f}}$ & $3.13^{\mathrm{e}}$ & $43.07^{\mathrm{e}}$ \\
\hline $80 \%$ & $3.47^{\mathrm{g}}$ & $115.67^{\mathrm{g}}$ & $1.79^{\mathrm{f}}$ & $16.76^{\mathrm{f}}$ \\
\hline
\end{tabular}

${ }^{1}$ Values with different superscript in the same column are significantly different at $95 \%$ confidence interval

Table 2. Ethanol precipitation of bromelain extract from MD2 peels ${ }^{1}$

\begin{tabular}{|l|c|c|c|c|}
\hline \multicolumn{1}{|c|}{ Fraction } & $\begin{array}{c}\text { Bromelain } \\
\text { activity, } \\
{[\mathbf{U} / \mathbf{m l}]}\end{array}$ & $\begin{array}{c}\text { Specific } \\
\text { activity, } \\
{[\mathbf{U} / \mathbf{m g}]}\end{array}$ & $\begin{array}{c}\text { Purification } \\
\text { factor }\end{array}$ & Yield, [\%] \\
\hline Crude extract & $17.58^{\mathrm{a}}$ & $76.43^{\mathrm{a}}$ & & \\
\hline $30 \%$ & $10.85^{\mathrm{b}}$ & $157.29^{\mathrm{b}}$ & $2.06^{\mathrm{ae}}$ & $61.73^{\mathrm{a}}$ \\
\hline $40 \%$ & $13.83^{\mathrm{c}}$ & $158.99^{\mathrm{c}}$ & $2.08^{\mathrm{ab}}$ & $78.68^{\mathrm{b}}$ \\
\hline $50 \%$ & $15.53^{\mathrm{d}}$ & $165.20^{\mathrm{d}}$ & $2.16^{\mathrm{c}}$ & $88.33^{\mathrm{c}}$ \\
\hline $60 \%$ & $12.92^{\mathrm{e}}$ & $161.50^{\mathrm{e}}$ & $2.11^{\mathrm{d}}$ & $73.49^{\mathrm{d}}$ \\
\hline $70 \%$ & $4.33^{\mathrm{f}}$ & $160.30^{\mathrm{f}}$ & $2.10^{\mathrm{db}}$ & $24.62^{\mathrm{e}}$ \\
\hline $80 \%$ & $2.35^{\mathrm{g}}$ & $156.47^{\mathrm{g}}$ & $2.05^{\mathrm{ea}}$ & $13.35^{\mathrm{f}}$ \\
\hline
\end{tabular}

${ }^{1}$ Values with different superscript in the same column are significantly different at $95 \%$ confidence interval

Table 3. Ethanol precipitation of bromelain extract from Sugarloaf crowns ${ }^{1}$

\begin{tabular}{|l|c|c|c|c|}
\hline \multicolumn{1}{|c|}{ Fraction } & $\begin{array}{c}\text { Bromelain } \\
\text { activity, } \\
{[\mathbf{U} / \mathbf{m l}]}\end{array}$ & $\begin{array}{c}\text { Specific } \\
\text { activity, } \\
{[\mathbf{U} / \mathbf{m g}]}\end{array}$ & $\begin{array}{c}\text { Purification } \\
\text { factor }\end{array}$ & Yield, [\%] \\
\hline Crude extract & $23.49^{\mathrm{a}}$ & $46.06^{\mathrm{a}}$ & & \\
\hline $30 \%$ & $9.74^{\mathrm{b}}$ & $109.44^{\mathrm{b}}$ & $2.38^{\mathrm{a}}$ & $41.46^{\mathrm{a}}$ \\
\hline $40 \%$ & $12.18^{\mathrm{c}}$ & $111.74^{\mathrm{c}}$ & $2.43^{\mathrm{b}}$ & $51.85^{\mathrm{b}}$ \\
\hline $50 \%$ & $19.98^{\mathrm{d}}$ & $143.74^{\mathrm{d}}$ & $3.12^{\mathrm{c}}$ & $85.06^{\mathrm{c}}$ \\
\hline $60 \%$ & $5.77^{\mathrm{e}}$ & $70.37^{\mathrm{e}}$ & $1.53^{\mathrm{d}}$ & $24.56^{\mathrm{d}}$ \\
\hline $70 \%$ & $2.59^{\mathrm{f}}$ & $64.75^{\mathrm{f}}$ & $1.41^{\mathrm{e}}$ & $11.03^{\mathrm{e}}$ \\
\hline $80 \%$ & $1.87^{\mathrm{g}}$ & $45.61^{\mathrm{g}}$ & $0.99^{\mathrm{f}}$ & $7.96^{\mathrm{f}}$ \\
\hline
\end{tabular}

${ }^{1}$ Values with different superscript in the same column are significantly different at $95 \%$ confidence interval 
Table 4. Ethanol precipitation of bromelain extract from Sugarloaf peels ${ }^{1}$

\begin{tabular}{|l|c|c|c|c|}
\hline \multicolumn{1}{|c|}{ Fraction } & $\begin{array}{c}\text { Bromelain } \\
\text { activity, } \\
{[\mathbf{U} / \mathbf{m l}]}\end{array}$ & $\begin{array}{c}\text { Specific } \\
\text { activity, } \\
{[\mathbf{U} / \mathbf{m g}]}\end{array}$ & $\begin{array}{c}\text { Purification } \\
\text { factor }\end{array}$ & Yield, [\%] \\
\hline Crude extract & $19.37^{\mathrm{a}}$ & $47.01^{\mathrm{a}}$ & & \\
\hline $30 \%$ & $10.40^{\mathrm{b}}$ & $150.72^{\mathrm{b}}$ & $3.21^{\mathrm{a}}$ & $53.69^{\mathrm{a}}$ \\
\hline $40 \%$ & $15.35^{\mathrm{c}}$ & $187.20^{\mathrm{c}}$ & $3.98^{\mathrm{b}}$ & $79.25^{\mathrm{b}}$ \\
\hline $50 \%$ & $17.27^{\mathrm{d}}$ & $133.88^{\mathrm{d}}$ & $2.85^{\mathrm{c}}$ & $89.16^{\mathrm{c}}$ \\
\hline $60 \%$ & $12.05^{\mathrm{e}}$ & $124.23^{\mathrm{e}}$ & $2.64^{\mathrm{d}}$ & $62.21^{\mathrm{d}}$ \\
\hline $70 \%$ & $6.49^{\mathrm{f}}$ & $94.06^{\mathrm{f}}$ & $2.00^{\mathrm{e}}$ & $33.51^{\mathrm{e}}$ \\
\hline $80 \%$ & $1.31^{\mathrm{g}}$ & $31.95^{\mathrm{g}}$ & $0.68^{\mathrm{f}}$ & $6.76^{\mathrm{f}}$ \\
\hline
\end{tabular}

${ }^{1}$ Values with different superscript in the same column are significantly different at $95 \%$ confidence interval

Table 5. Ammonium sulphate precipitation of bromelain extract from $M D 2$ crowns $^{1}$

\begin{tabular}{|l|c|c|c|c|}
\hline \multicolumn{1}{|c|}{ Fraction } & $\begin{array}{c}\text { Bromelain } \\
\text { activity, } \\
{[\mathbf{U} / \mathbf{m l}]}\end{array}$ & $\begin{array}{c}\text { Specific } \\
\text { activity, } \\
{[\mathbf{U} / \mathbf{m g}]}\end{array}$ & $\begin{array}{c}\text { Purification } \\
\text { factor }\end{array}$ & Yield, [\%] \\
\hline Crude extract & $20.71^{\mathrm{a}}$ & $64.72^{\mathrm{a}}$ & & \\
\hline $30 \%$ & $9.83^{\mathrm{b}}$ & $131.07^{\mathrm{b}}$ & $2.03^{\mathrm{a}}$ & $47.46^{\mathrm{a}}$ \\
\hline $40 \%$ & $19.28^{\mathrm{c}}$ & $241.00^{\mathrm{c}}$ & $3.72^{\mathrm{b}}$ & $93.10^{\mathrm{b}}$ \\
\hline $50 \%$ & $13.09^{\mathrm{d}}$ & $192.50^{\mathrm{d}}$ & $2.97^{\mathrm{c}}$ & $63.21^{\mathrm{c}}$ \\
\hline $60 \%$ & $12.14^{\mathrm{e}}$ & $168.61^{\mathrm{e}}$ & $2.61^{\mathrm{d}}$ & $58.62^{\mathrm{d}}$ \\
\hline $70 \%$ & $6.78^{\mathrm{f}}$ & $178.42^{\mathrm{f}}$ & $2.76^{\mathrm{e}}$ & $32.74^{\mathrm{e}}$ \\
\hline $80 \%$ & $2.28^{\mathrm{g}}$ & $91.20^{\mathrm{g}}$ & $1.41^{\mathrm{f}}$ & $11.01^{\mathrm{f}}$ \\
\hline
\end{tabular}

${ }^{1}$ Values with different superscript in the same column are significantly different at $95 \%$ confidence interval

Table 6. Ammonium sulphate precipitation of bromelain extract from MD2 peels ${ }^{1}$

\begin{tabular}{|l|c|c|c|c|}
\hline \multicolumn{1}{|c|}{ Fraction } & $\begin{array}{c}\text { Bromelain } \\
\text { activity, } \\
{[\mathbf{U} / \mathbf{m l}]}\end{array}$ & $\begin{array}{c}\text { Specific } \\
\text { activity, } \\
{[\mathbf{U} / \mathbf{m g}]}\end{array}$ & $\begin{array}{c}\text { Purification } \\
\text { factor }\end{array}$ & Yield, [\%] \\
\hline Crude extract & $17.58^{\mathrm{a}}$ & $76.43^{\mathrm{a}}$ & & \\
\hline $30 \%$ & $9.24^{\mathrm{b}}$ & $159.31^{\mathrm{b}}$ & $2.08^{\mathrm{a}}$ & $52.56^{\mathrm{a}}$ \\
\hline $40 \%$ & $16.79^{\mathrm{c}}$ & $188.65^{\mathrm{c}}$ & $2.47^{\mathrm{b}}$ & $95.51^{\mathrm{b}}$ \\
\hline $50 \%$ & $14.21^{\mathrm{d}}$ & $177.63^{\mathrm{d}}$ & $2.32^{\mathrm{c}}$ & $80.83^{\mathrm{c}}$ \\
\hline $60 \%$ & $11.78^{\mathrm{e}}$ & $175.82^{\mathrm{e}}$ & $2.30^{\mathrm{d}}$ & $67.01^{\mathrm{d}}$ \\
\hline $70 \%$ & $5.83^{\mathrm{f}}$ & $149.49^{\mathrm{f}}$ & $1.96^{\mathrm{e}}$ & $33.16^{\mathrm{e}}$ \\
\hline $80 \%$ & $2.93^{\mathrm{g}}$ & $94.52^{\mathrm{g}}$ & $1.24^{\mathrm{f}}$ & $16.67^{\mathrm{f}}$ \\
\hline
\end{tabular}

${ }^{1}$ Values with different superscript in the same column are significantly different at $95 \%$ confidence interval 
Table 7. Ammonium sulphate precipitation of bromelain extract from Sugarloaf crowns ${ }^{1}$

\begin{tabular}{|l|c|c|c|c|}
\hline \multicolumn{1}{|c|}{ Fraction } & $\begin{array}{c}\text { Bromelain } \\
\text { activity, } \\
{[\mathbf{U} / \mathbf{m l}]}\end{array}$ & $\begin{array}{c}\text { Specific } \\
\text { activity, } \\
{[\mathbf{U} / \mathbf{m g}]}\end{array}$ & $\begin{array}{c}\text { Purification } \\
\text { factor }\end{array}$ & Yield, [\%] \\
\hline Crude extract & $23.49^{\mathrm{a}}$ & $46.06^{\mathrm{a}}$ & - & \\
\hline $30 \%$ & $8.23^{\mathrm{b}}$ & $83.13^{\mathrm{b}}$ & $1.80^{\mathrm{a}}$ & $35.04^{\mathrm{a}}$ \\
\hline $40 \%$ & $20.82^{\mathrm{c}}$ & $194.58^{\mathrm{c}}$ & $4.22^{\mathrm{b}}$ & $88.63^{\mathrm{b}}$ \\
\hline $50 \%$ & $12.73^{\mathrm{d}}$ & $136.88^{\mathrm{d}}$ & $2.97^{\mathrm{c}}$ & $54.19^{\mathrm{c}}$ \\
\hline $60 \%$ & $9.18^{\mathrm{e}}$ & $145.71^{\mathrm{e}}$ & $3.16^{\mathrm{d}}$ & $39.08^{\mathrm{d}}$ \\
\hline $70 \%$ & $4.04^{\mathrm{f}}$ & $73.06^{\mathrm{f}}$ & $1.59^{\mathrm{e}}$ & $17.20^{\mathrm{e}}$ \\
\hline $80 \%$ & $3.15^{\mathrm{g}}$ & $65.63^{\mathrm{g}}$ & $1.42^{\mathrm{f}}$ & $13.41^{\mathrm{f}}$ \\
\hline
\end{tabular}

${ }^{1}$ Values with different superscript in the same column are significantly different at $95 \%$ confidence interval

Table 8. Ammonium sulphate precipitation of bromelain extract from Sugarloaf peels ${ }^{1}$

\begin{tabular}{|l|c|c|c|c|}
\hline \multicolumn{1}{|c|}{ Fraction } & $\begin{array}{c}\text { Bromelain } \\
\text { activity, } \\
{[\mathbf{U} / \mathbf{m l}]}\end{array}$ & $\begin{array}{c}\text { Specific } \\
\text { activity, } \\
{[\mathbf{U} / \mathbf{m g}]}\end{array}$ & $\begin{array}{c}\text { Purification } \\
\text { factor }\end{array}$ & Yield, [\%] \\
\hline Crude extract & $19.37^{\mathrm{a}}$ & $47.01^{\mathrm{a}}$ & & \\
\hline $30 \%$ & $14.31^{\mathrm{b}}$ & $181.14^{\mathrm{b}}$ & $3.85^{\mathrm{a}}$ & $73.88^{\mathrm{a}}$ \\
\hline $40 \%$ & $18.03^{\mathrm{c}}$ & $158.16^{\mathrm{c}}$ & $3.36^{\mathrm{b}}$ & $93.08^{\mathrm{b}}$ \\
\hline $50 \%$ & $10.27^{\mathrm{d}}$ & $86.30^{\mathrm{d}}$ & $1.84^{\mathrm{c}}$ & $53.02^{\mathrm{c}}$ \\
\hline $60 \%$ & $7.38^{\mathrm{e}}$ & $91.11^{\mathrm{e}}$ & $1.94^{\mathrm{d}}$ & $38.10^{\mathrm{d}}$ \\
\hline $70 \%$ & $4.96^{\mathrm{f}}$ & $97.25^{\mathrm{f}}$ & $2.07^{\mathrm{e}}$ & $25.61^{\mathrm{e}}$ \\
\hline $80 \%$ & $2.76^{\mathrm{g}}$ & $78.86^{\mathrm{g}}$ & $1.68^{\mathrm{f}}$ & $14.25^{\mathrm{f}}$ \\
\hline
\end{tabular}

${ }^{1}$ Values with different superscript in the same column are significantly different at $95 \%$ confidence interval

Using the ethanol precipitation technique, bromelain activity of $M D 2$ pineapple peels ranged from $17.58 \mathrm{U} / \mathrm{ml}$ for the crude extract (i.e. $0 \%$ precipitation) to $2.35 \mathrm{U} / \mathrm{ml}$ for the $80 \%$ precipitation level. Enzyme activity peaked at the $50 \%$ precipitation level. Bromelain activity of $M D 2$ crowns were higher than that of the peels. The crude extract of the crowns had an activity of $20.71 \mathrm{U} / \mathrm{ml}$ and the highest enzyme activity for the precipitated fractions was $18.01 \mathrm{U} / \mathrm{ml}$ which was observed at the $50 \%$ precipitation level. The bromelain activity was seen to increase from the $30 \%$ level to the $50 \%$ level and then decrease to the $80 \%$ level in both crowns and peels. Specific activity, an index of purity, on the other hand was highest in the $60 \%$ precipitated fraction of $M D 2$ crowns indicating that this fraction was the purest. This finding is supported by the purification factor. The highest purification factor among the $M D 2$ crowns, 3.39 was also observed at the $60 \%$ precipitation level.

In precipitation with ethanol, there is dehydration of proteins resulting in an increase in protein-protein interactions and a decrease in protein-water interactions. An increase in the concentration of the solvent results in a decrease in the solubility of the proteins, thus an increase in the amount of proteins that are precipitated [24]. This occurs together with a lowering of the permittivity resulting in an increase in inter and intra-molecular electrostatic forces culminating in 
the unfolding of the protein structure [25]. An enzyme activity of $15.96 \mathrm{U} / \mathrm{ml}$ in the $30 \%-70 \%$ precipitation range was obtained by [12]. However, it is difficult to make a good comparison as various waste parts of pineapple were homogenised together in that study. Results obtained in the present study are higher than that obtained by [26] in ripe pineapple fruits.

In the case of ammonium sulphate precipitation, bromelain activity of Sugarloaf crowns ranged from $23.49 \mathrm{U} / \mathrm{ml}$ for the crude extract to $3.15 \mathrm{U} / \mathrm{ml}$ for the $80 \%$ precipitation level. An enzyme activity of $20.82 \mathrm{U} / \mathrm{ml}$ was recorded at the $40 \%$ precipitation level. The fraction here also had an activity of $194.58 \mathrm{U} / \mathrm{mg}$ and a yield of $88.63 \%$. As in the case of ethanol precipitation, the crowns had higher enzyme activities than the peels. The crude extract of the peels had an activity of $19.37 \mathrm{U} / \mathrm{ml}$ and the highest enzyme activity for the precipitated peel fractions was $18.03 \mathrm{U} / \mathrm{ml}$ which was observed at the $40 \%$ precipitation level. Enzyme activity was higher in the Sugarloaf variety. The $40 \%$ precipitation level appears to be the level where the highest bromelain activity can be achieved.

[27] also achieved a $31.97 \mathrm{U} / \mathrm{ml}$ enzyme activity in the $20 \%-40 \%$ precipitation in a study on ammonium sulphate precipitation of bromelain. The differences between the results obtained in this study and the results from $[12,13,27]$ can be attributed to varietal differences and differences in soil conditions. The concentration and activity of bromelain in pineapples is dependent on the variety of the pineapple, the part from which it is extracted, climatic conditions during plant growth and particularly the soil type [5]. Comparison of results between different enzyme studies presents a challenge due to the lax in methods of enzyme activity assay.

Based on the specific activities shown in the results, the purest fraction had a specific activity of $241.00 \mathrm{U} / \mathrm{mg}$. This was from the MD2 crowns at the $40 \%$ precipitation level using ammonium sulphate. Similar findings were reported by [27]. Though the crude fractions of both MD2 and Sugarloaf had the highest enzyme activity, as expected, these fractions also had the lowest specific activity. This underscores the need for further purification of crude enzymes to increase their specific activity. Usually in industrial applications, the yield of enzymes is prioritised over its purity, although for specialty enzymes it is the purity that is prioritised [14]. Purification factor and yield ranged from 1.53 to 3.98 and $24.56 \%$ to $95.51 \%$ respectively in the $30-60 \%$ precipitation range. Higher yields and folds of purification have been achieved using methods such as micro and ultrafiltration, aqueous two phase systems [1].

\section{Conclusion}

Bromelain was precipitated by both ethanol and ammonium sulphate mainly in the $30 \%-60 \%$ precipitation range. The Sugarloaf variety had higher enzyme activity than the MD2 variety. The crowns of both varieties also have higher enzyme activity than their respective peels. The crown and peels of both varieties have significant amounts of bromelain activity and can be exploited for commercial production. Looking forward, the utilisation of pineapple waste in bromelain production will help in the reduction of pineapple waste. Further research can be carried out to maximise the use of pineapple waste for bromelain and the economic viability of the process.

\section{Conflict of Interest}

Authors declare that there is no conflict of interest.

\section{References}

[1] A. Amid et al., Bromelain production: current trends and perspective, Archives Des Sciences. 65(11) (2012) 369-399.

[2] S. Kumar, A.B. Hemavathi, H.U. Hebbar, Affinity based reverse micellar extraction and purification of bromelain from pineapple (Ananas comosus) waste, Process Biochemistry. 46 (2011) 1216-1220. 
[3] H.Y. Liang et al., Study on the stability of fruit bromelain, Advanced Materials Research. 421 (2011) 19-22.

[4] A.N.M. Ramli et al., Comparative structural analysis of fruit and stem bromelain from Ananas comosus, Food Chemistry. 266 (2018) 183-191.

[5] B. Tochi et al., Therapeutic application of pineapple protease (Bromelain): A Review, Pakistan Journal of Nutrition. 7(4) (2008) 513-520.

[6] W. Aehle, Enzymes in industry: production and applications, Third Ed., Wiley-VCH/Verlag GmbH \& Co., Weinheim, 2007.

[7] B.K. Bhattacharrya, Bromelain: Overview, Natural Product Radiance. 7(4) (2008) 359-363.

[8] J.A. Ataide et al., Bromelain-loaded nanoparticles: A comprehensive review of the state of the art, Advances in Colloid and Interface Science. 254 (2018) 48-55.

[9] G.M. Sancesario et al., Bromelain degrades A $\beta 1-42$ monomers and soluble aggregates: an in vitro study in cerebrospinal fluid of Alzheimer's disease patients, Current Alzheimer Research. 15(7) (2018) 628-636.

[10] G. Swaroop, G. Viswanathan, Isolation and characterization of bromelain (BML) proteases from Ananas comosus an asset to cancer chemotherapy, International Journal of Pharmacology and Toxicology. 1(2) (2013) 82-90.

[11] S.S. Gautam et al., Comparative study of extraction, purification and estimation of bromelain from stem and fruit of pineapple plant, Thai Journal of Pharmaceutical Sciences. 34 (2010) 67-76.

[12] B. Martins, Characterization of bromelain from Ananas Comosus agroindustrial residues purified by ethanol factional precipitation, Chemical Engineering Transactions. 37 (2014) 781-786.

[13] I.R.A.P. Bresolin, isolation and purification of bromelain from waste peel of pineapple for therapeutic application, Brazilian Archives of Biology and Technology. 56(6) (2013) 971979.

[14] A. Illanes, Enzyme Production, in: Enzyme Biocatalysis, Springer Science and Business Media V.B, Brazil, 2008, pp. 57-106.

[15] S. Ketnawa, S. Rawdkuen, S.P. Chaiwut, Two phase partitioning and collagen hydrolysis of bromelain from pineapple peel (Nang Lae cultivar), Journal of Biochemical Engineering. 52 (2010) 205-211.

[16] J.F. Ferreira, Purification of bromelain from Ananas comosus by PEG/Phosphate ATPS, Chemical Engineering Transactions. 24 (2011) 931-936

[17] L.S. Gil, P.F. Maupoey, An integrated approach for pineapple waste valorisation. Bioethanol production and bromelain production from pineapple residues, Journal of Cleaner Production. 172 (2018) 1224-1231.

[18] A. Arumugam, V. Ponnusami, Pineapple fruit bromelain recovery using recyclable functionalized ordered mesoporous silica synthesized from sugarcane leaf ash, Brazilian Journal of Chemical Engineering. 30(3) (2013) 477-486.

[19] R.K. Scopes, Enzyme activity and assays, in: Encyclopaedia of Life Sciences, Macmillan Publishers Ltd, 2002.

[20] FAO, Production quantities of Pineapple by country [Online]. Available: http://www.fao.org/faostat/en/\#data/OC. 
[21] D.P. Bartholomew, R.E. Paul, K.G. Rohrbach, The pineapple: botany, production and uses, First Ed., CABI Publishing, Wallingford-UK, 2003.

[22] S. Englard, S. Seifter, Precipitation techniques, Methods of Enzymology. 18 (1990) 287-300.

[23] S. Ketnawa et al., Partitioning bromelain from pineapple peel (Nang Lae cultivar) by aqueous two phase system, Asian Journal of Food and Agro-industry. 2(04) (2009) 457-468.

[24] S. Damodaran, Amino acids, peptides and proteins, in: O.R. Fennema (Ed.), Food Chemistry, Marcel Dekker Inc, New York, 1996, pp. 371-373.

[25] Z.E. Sikorski, Proteins, in: Z.E. Sikorski (Ed.), Chemical and Functional Properties of Food Components, CRC Press, Boca Raton, 2002, pp. 143.

[26] S.P. Priya et al., Immobilization and kinetic studies of bromelain: a plant cysteine protease from pineapple (Ananas comosus) plant parts, International Journal of Medical and Health Sciences. 1(3) (2012) 10-16.

[27] P. Soares, Studies on bromelain precipitation by ethanol, poly (ethylene glycol) and ammonium sulphate, Brazilian Archives of Biology and Technology. 57(1) (2014) 971-979. 